\title{
DMSO-enhanced whole cell yeast transformation
}

\author{
James Hill, K.A.Ian G.Donald and David E.Griffiths \\ Department of Chemistry, University of Warwick, Coventry CV4 7AL, UK
}

Submitted August 22, 1991

The transformation efficiency of Saccharomyces cerevisiae by the lithium acetate ( $\mathrm{LiOAc})$ method (1) is low compared with spheroplast (2) and electroporation (3) protocols. It is, however, quick and simple, making it ideal when a high efficiency of transformation is not essential. Dimethyl sulfoxide (DMSO) has previously been shown to enhance transformation of prokaryotes (4) and eukaryotes (5). We report a DMSO-modified version of an existing yeast LiOAc transformation method (6) that is quicker, and more efficient than the original method. The method below gives optimal transformation efficiency for S.cerevisiae JRY188 (MAT $\alpha$ leu2-3, 112, his3 $\Delta 1, \operatorname{trp}-289$, ura3-52, sir3-8):

1. A stationary culture of JRY188 grown in YEPD is used to inoculate $100 \mathrm{ml}$ of YEPD in a Pyrex flask.

2. Cells are grown at $30^{\circ} \mathrm{C}$ with shaking $(200 \mathrm{rpm})$ until a cell density of $1-4 \times 10^{7}$ is reached. Yeast are transferred to four sterile $30 \mathrm{ml}$ plastic disposable tubes and centrifuged at $4000 \mathrm{rpm}$ for 2 minutes at room temperature.

3. The pellets are washed in $10 \mathrm{ml}$ total of LiOAc solution $(0.1$ M LiOAc, $10 \mathrm{mM}$ Tris $\mathrm{HCl}$ (pH 8.0) $1 \mathrm{mM}$ EDTA) and pooled into a single tube. The suspension is centrifuged as before then resuspended by adding $1 \mathrm{ml}$ of LiOAc solution and gently shaking by hand.

4. $100 \mu \mathrm{l}$ of yeast suspension is added to a $1.5 \mathrm{ml}$ centrifuge tube containing $10 \mu \mathrm{l}$ of transforming DNA. The contents are mixed gently then left at room temperature for 5 mins.

5. $280 \mu \mathrm{l}$ of PEG4000 solution (50\% PEG4000, (Fisons) in LiOAc solution) is added, the contents mixed by inverting 4-6 times, then the tube is placed at $30^{\circ} \mathrm{C}$ for 45 mins without shaking.

6. DMSO is added ( $43 \mu \mathrm{l})$ to give an approximate $10 \%(\mathrm{v} / \mathrm{v})$ DMSO solution in the tube. The contents are mixed by inversion then heat shocked at $42^{\circ} \mathrm{C}$ for 5 mins.

7. Cells are spun at $12000 \mathrm{~g}$ just long enough to pellet (usually 3-5 seconds), washed in $\mathrm{dH}_{2} \mathrm{O}$, spun for 3 seconds, then


derivative of YEp351 (7) was used to transform JRY188 $(1 \mu \mathrm{g}$ per assay). Transformed cells $(100 \mu \mathrm{l})$ were plated on SD media supplemented with histidine, uracil and tryptophan (8), and transformants scored after 3 days at $30^{\circ} \mathrm{C}$. Efficiency was calculated as the number of $L E U 2$ transformants per $\mu \mathrm{g}$ DNA. Results shown (Table 1) are the average of four separate tubes per method.

The importance of $\mathrm{Li}^{+}$in this protocol was assessed by transforming JRY188 in the absence if $\mathrm{Li}^{+}$. This was done by washing cells in TE buffer, and using PEG4000 dissolved in TE. The efficiency in the absence of LiOAc $\left(-\mathrm{Li}^{+}\right)$is more than halved, but is still significantly greater than the control. This technique may therefore prove useful with yeast strains that transform poorly with the $\mathrm{LiOAc}$ or $\mathrm{Ca}^{2+}(9)$ methods, as
DMSO improves transformation in the absence of any cations. Carrier DNA did not enhance any of the transformation methods described; this may be due to non-denatured sheared calf thymus DNA being used (10).

Transformation of another strain of S.cerevisiae with a dominant marker (G418 ${ }^{\text {res}}$ ) has been demonstrated using the above protocol; a $90 \mathrm{~min}$ incubation in YEPD (8) is necessary, prior to selection for $\mathrm{G} 418^{\mathrm{res}}$. A derivative of the centromeric plasmid YCp50 was used as transforming DNA. Similar enhancement of transformation was observed although optimal efficiency was achieved at a slightly different DMSO concentration. This is indicative of strain specificity with yeast whole cell transformation. It also demonstrates that the above protocol works for other strains and large centromeric plasmids. This may prove to be a quick, technically simple, and efficient method of whole cell yeast transformation.

\section{ACKNOWLEDGEMENTS}

We thank SERC and Whitbread plc for financial support, and Dr C. Hadfield for providing a yeast G418 ${ }^{\text {res }}$ marker (11).

\section{REFERENCES}

1. Ito,H., Fukuda,Y., Murata,K. and Kimura,J. (1983) J. Bacteriol. 153, $163-168$.

2. Beggs,J.D. (1978) Nature (London) 275, 104-108.

3. Becker,D.M. and Guarente,L. (1991) Methods Enzymol. 194, 182-187.

4. Chung,C.T. and Miller,R.H. (1988) Nucl. Acids Res. 16, 3580.

5. Lopata,M.A., Cleveland,D.W. and Sollner-Webb,B. (1984) Nucl. Acids Res. 12, 5707-5717.

6. Ausubel,F.M., Brent,R., Kingston,R.E., Moore,D.D., Seidmann,J.G., Smith,J.A. and Struhl,K. (1989) Current Protocol in Molecular Biology. vol. 2, Wiley-Interscience, New York.

7. Hill,J.E., Myers,A.M., Koermer,J. and Tzagoloff,A. (1986) Yeast 2, $163-167$.

8. Sherman,F. (1991) Methods Enzymol. 194, 14-15.

9. Bruschi,C.V., Comer,A.R. and Howe,G.A. (1987) Yeast 3, 131-138.

10. Schiestl,R.H. and Geitz,R.D. (1989) Curr. Genet. 16, 339-346.

11. Hadfield,C., Jordan,B.E., Mount,R.C., Pretorius,G.H.J. and Burak,E. (1990) Curr. Genet. 18, 303-313.

Table 1. Comparison of transformation method

\begin{tabular}{lll}
\hline METHOD & EFFICIENCY & ENHANCEMENT \\
\hline NORMAL & $1589 \pm 338$ & - \\
DMSO $\left(-\mathrm{Li}^{+}\right)$ & $18970 \pm 1340$ & $\times 11.9$ \\
DMSO $\left(+\mathrm{Li}^{+}\right)$ & $41070 \pm 6700$ & $\times 25.8$ \\
\hline
\end{tabular}

